\title{
A estrutura dinâmica da liturgia: uma abordagem na perspectiva do realismo de Xavier Zubiri
}

\author{
The dynamic structure of de liturgy: \\ approach in the perspective Xavier Zubiri's realism
}

\section{Resumo}

A liturgia é ação ritual da Igreja, que por meio de ritus et preces atualiza, a salvação em andamento na história e na vida de cada pessoa. Para isso a liturgia, em seu cristocentrismo trinitário, é dinâmica por natureza. Portanto, não precisa de nenhum adendo extra-ritual para sua eficácia, pois tornam-se interferências equivocadas que ferem o direito litúrgico dos fiéis de participar de uma liturgia autêntica e de qualidade. Por meio dos ritos, a liturgia significa e "realiza" o que significa. Porém uma hermenêutica equivocada da reforma litúrgica do Concílio Ecumênico Vaticano II levou a interferências nefastas na ritualidade litúrgica. Baseados no realismo do filósofo Xavier Zubiri, analisaremos o "poder do real" na realidade dinâmica dos ritos litúrgicos.

Palavras-chave: Liturgia. Dinamismo. Poder. Eficácia. Realidade. Salvação.

\section{Abstract}

The liturgy is a ritual action of the Church, which through ritus et preces, actualizes salvation in progress in the history and in the life of each person. For this, the liturgy, in its Christocentric-Trinitarian, is dynamic by nature. Therefore, it does not need any extra-ritual additions to its effectiveness, 
because they become mistaken interferences that damage the liturgical right of the faithful to participate in an authentic and quality liturgy. Through ritual, liturgy means and "realizes" what it means. But a misleading hermeneutic of the liturgical reform of the Second Vatican Council led to nefarious interference in liturgical rituality. Based on the philosopher Xavier Zubiri's realism, we will analyze the "power of the real" in the dynamic reality of liturgical rites.

Keywords: Liturgy. Dynamism. Power. Effectiveness. Reality. Salvation.

\section{Introdução}

Um dos momentos mais intensos de se viver o dinamismo da fé é a celebração litúrgica do Mistério Pascal de Cristo. Areforma litúrgica promovida pelo Concílio Ecumênico Vaticano II, preocupado com o dinamismo da liturgia, que estava "engessada" pelo que se chamou de rubricismo, trouxe de volta a criatividade litúrgica. No entanto, um certo clima iluminista favoreceu uma interpretação equivocada que gerou interferências externas ao rito, desconsiderando que o dinamismo próprio da liturgia está em si mesma e não em agentes externos. Em seus diversos tons de gravidade, constituíram-se os abusos já apontados pelos vários documentos pós-conciliares do Magistério. Neste artigo, fazemos interface com o filósofo contemporâneo Xavier Zubiri, cujo realismo trouxe uma luz para o conhecimento. Dessa forma, reafirmamos que o dinamismo da liturgia está em seu próprio rito e não em penduricalhos que lhe são impostos de fora.

\section{O dinamismo próprio da liturgia}

Depois da reforma litúrgica promovida pelo Concílio Ecumênico Vaticano II, diversos grupos da Igreja tentaram encontrar o dinamismo da liturgia, que a partir da reforma tridentina foi ficando "engessada" em normas rígidas, dando clara impressão de ter perdido seu dinamismo próprio. A reforma tridentina foi necessária para enfrentar um tipo de evolução desmedida que assimilou adendos impróprios provindos da idade média tardia, sobretudo na Eucaristia. Isso gerou na liturgia uma desorganização tal, chegando ao perigo da implosão de sua estrutura. ${ }^{1}$ Havia já naquela época um desejo de purificar a liturgia e

\footnotetext{
${ }^{1}$ BERGER, R., Dicionário de liturgia pastoral, p. 348.
} 
retornar às fontes da antiguidade cristã. Segundo Berger, a reforma tridentina não logrou alcançar o objetivo de retornar às fontes da antiguidade cristã, mas "o que de fato conseguiu fazer foi tão somente eliminar, mediante a nova edição dos livros litúrgicos mais importantes, muitas situações impróprias, sobretudo no nível local". ${ }^{2}$ Cada vez mais a liturgia do rito romano foi se tornando uniforme em toda parte, desde o uso da língua latina até a forma proporcional de executar rigidamente os ritos. A isso se chamou de "engessamento". E por que ocorreu um engessamento desses? Ocorreu porque, sem dúvida, havia o medo de se voltar à situação anterior, pois

o medo de recaídas nas anteriores excrescências levou a uma fixação rubricista, por cuja observância a Congregação dos Ritos, fundada em 1558 especificamente para isso, deveria zelar. Essa medida logrou manter a liturgia católica a salvo durante o iluminismo, mas ao mesmo tempo a afastou cada vez mais da vida real da comunidade. ${ }^{3}$

A liturgia é uma das ações mais dinâmicas da Igreja, seja pela sua etimologia, que em grego carrega o dinamismo de "ação" e de "trabalho", seja pelo seu contundente poder de atuar em todas as dinâmicas pessoais e sociais abarcadas pelo fato litúrgico, como diz López Martín:

A liturgia cristã é uma realidade muito rica e polivalente que pode ser analisada sob numerosos aspectos. É inegável que se trata de uma realidade unida à fé e à expressão pessoal e social dos membros da Igreja. Isto faz com que a ciência que tem como objeto a liturgia, procure abarcar todos os aspectos do fato litúrgico e de maneira particular os que se referem à sua realização atual. ${ }^{4}$

Depois de anos de luta pessoal para fazer alunos e leitores entenderem que a liturgia tem uma dinâmica própria, e que dispensa aquele tipo de criatividade que interrompa o rito com ações de natureza não ritual, ${ }^{5}$ nos propomos, apoiados no realismo de Xavier Zubiri (1898-1983), argumentar o que estamos insistindo há muito tempo. É uma grande preocupação não

\footnotetext{
${ }^{2}$ BERGER, R., Dicionário de liturgia pastoral, p. 348.

${ }^{3}$ BERGER, R, Dicionário de liturgia pastoral, p. 348.

${ }^{4}$ LÓPEZ MARTÍN, J., La liturgia de la Iglesia, p. 3.

${ }^{5}$ Para aprofunda este tema ler: COSTA, V. S., Viver a ritualidade litúrgica como momento histórico da salvação.
} 
só para os que lutam no campo da ciência litúrgica, mas sobretudo, para o povo de Deus, que está cansado desse tipo de criatividade e tem direito a uma liturgia autêntica e de qualidade, para poder celebrar sua fé com eficácia. ${ }^{6}$ Há também os que apoiam tais liturgias, servindo-se delas com a finalidade de diversão. Neste caso, faz pena, porque tal distorção beira o "pão e circo" do paganismo romano.

Quando Cristo instituiu a Eucaristia na Santa Ceia, matriz de toda liturgia cristã, não lhe deu o mínimo caráter de teatro ou show para divertir, mas instituiu o momento mais delicado e profundo da nossa salvação, do qual só poderiam participar os iniciados, isto é, aqueles que, por aderência ao Homem-Deus, são capazes de apreender a grandeza do mistério ali celebrado, comprometendo toda a sua vida no horizonte a que a simbologia litúrgica conduz. Podemos deduzir do pensamento de Jung que a Missa foi instituída para os que são capazes de símbolo. ${ }^{7}$ E símbolo não atua na região periférica, mas no profundo do sentimento humano. Fazer da Missa uma peça de diversão é uma deformação daquele Sacrifício redentor, que tem o formato de ceia, mas que realiza a comunhão com a profundidade do mistério, englobando a dor e a alegria. Nesse sentido, o próprio Jung diz:

O aparecimento de uma ordem supratemporal no sacrifício da missa pressupõe a ideia de transformação no sentido de um milagre que tem lugar "vere, realiter et substancialiter" (verdadeira, real $\mathrm{e}$ substancialmente) (sic), visto que os dons oferecidos aparentemente em nada diferem de objetos naturais, concretos, e devem, inclusive, ser constituídos de substâncias naturais bem determinadas e universalmente conhecidas, como sejam a farinha de trigo transformada em pão e o vinho puramente natural. ${ }^{8}$

Como fazer de um momento desses um teatro e, às vezes, uma diversão tão superficial como para os romanos pagãos era o circo? É banalizar uma presença e uma ação carregada de mistério e vida! Ainda Jung diz, falando de Cristo:

Mas a sua presença não é um reaparecimento; consequentemente

\footnotetext{
${ }^{6}$ Sobre esse tema ler: COSTA, V. S., Direito Litúrgico, p. 729-747.

${ }^{7}$ JUNG, K. G., O símbolo da transformação da missa, p. 15.

${ }^{8}$ JUNG, K. G., O símbolo da transformação da missa, p. 14-15.
} 
a consagração não é a repetição de um ato histórico e único, mas a expressão visível de um fato que perdura eternamente, o rasgar-se dos condicionamentos temporais e espaciais que separa o espírito humano da visão do eterno. Esse acontecimento é, necessariamente, um mistério, pois se situa além da capacidade humana de compreensão, e isto quer dizer que o rito da missa é, necessariamente, um símbolo. ${ }^{9}$

Fica claro que Jung, como cientista que vasculhou a mente humana, viu na missa o lugar próprio da ação simbólica. E símbolo é um tipo de dinamismo muito específico que não vamos estudar aqui. O que vamos fazer agora é aprofundar o dinamismo da realidade, a partir de Zubiri. Na segunda citação acima, de López Martín, aparece por duas vezes a palavra realidade, que tem peso central na filosofia realista de Zubiri. É a isto que vamos nos dedicar agora. Antes de estudar realidade em Zubiri, vamos falar de Zubiri e da revolução representada pelo seu pensamento, sintetizado em torno da expressão "inteligência senciente".

\section{Xavier Zubiri e inteligência senciente}

Zubiri (1898-1983) ${ }^{10}$ é um filósofo contemporâneo, cujo realismo constitui uma revolução, a nosso ver, pois reformula fundamentalmente o pensamento que chegou até nosso tempo. Neste sentido, Zubiri é considerado por Ellacuria "um hipercrítico, um revolucionário em filosofia, um educador para a liberdade crítica do pensamento": ${ }^{11}$

Zubiri acabou desenvolvendo uma filosofia não só diferente, mas radicalmente nova, a partir do que se pode compreender como uma crítica radical de toda a filosofia anterior; e ele teve êxito em colocar todos os problemas em outro plano, para terminar com uma nova visão de realidade. ${ }^{12}$

\footnotetext{
${ }^{9}$ JUNG, K. G., O símbolo da transformação da missa, p. 15. infinito; TEJADA, J. F., Prefácio, p. IX-XIX.

${ }^{11}$ ELLACURIA, I., Uma abordagem da filosofia de Zubiri, p. 35.

${ }^{12}$ ELLACURIA, I., Uma abordagem da filosofia de Zubiri, p. 35.
}

${ }^{10}$ Para falar de Zubiri, apoiamo-nos sobretudo em seus textos, mas também em seus comentadores, dentre os quais salientamos: CAPONIGRI, A. R., Propósito de sobre a essência, p. 47-64; ELLACURIA, I., Uma abordagem da filosofia de Zubiri, p. 33-45; FERRAZ FAYOS, A., A trilogia sobre a inteligência, p. 65-76; GRACIA, D., Zubiri (1898-1983), p. 15-32; PINTOR -RAMOS, A., Uma filosofia da religião cristã, p. 77-108; TEIXEIRA, J. A. P., A finitude do 
A filosofia de Zubiri é transversalmente teológica. A sua obra El hombre $y$ Dios,${ }^{13}$ que mantém o caráter filosófico, editada pela primeira em 1984, é, a nosso ver, sua magna entrada no mundo da Teologia, o que era seu desejo depois de ter escrito a trilogia sobre a "inteligência senciente", ${ }^{14}$ obra em que sistematiza rigorosamente seu pensamento. A expressão "inteligência senciente" condensa a vastidão revolucionária do pensamento zubiriano, em sua luta para escapar do que ele chama de "inteligência concipiente". Esta se opõe à "inteligência senciente" pois expressa uma teoria do conhecimento em que sentir e inteligir são faculdades distintas e até opostas. Foi a evolução histórica da Filosofia:

Ao longo de toda a história, a filosofia tratou muito detidamente dos atos de intelecção (conceber, julgar, etc.), em contraposição aos diferentes dados reais que os sentidos nos fornecem. Uma coisa, diz-se-nos, é sentir, outra é inteligir. Esse enfoque do problema da inteligência contém, no fundo, uma afirmação: inteligir é posterior a sentir, e essa posteridade é uma oposição. Foi a tese inicial da filosofia desde Parmênides, que veio gravitando imperturbavelmente, com mil variantes, em torno de toda a filosofia europeia. ${ }^{15}$

Inteligência Senciente é o modo de inteligir estruturalmente vinculado ao sentir. Assim o sentir humano é intelectivo tanto quanto o inteligir é senciente. Reconhecer isso como um fato que não se pode contestar foi a grande contribuição de Zubiri para o homem de hoje, dividido e a se debater com sua própria esquizofrenia, por fazer do sentir e do inteligir faculdades separadas e até opostas. A filosofia de Zubiri iluminou o horizonte e trouxe de volta a unidade que faz do homem um animal de sentimento e pensamento, um animal inteligente que representa a unidade do Universo. É, portanto um fato inconteste que sentir e inteligir é um momento uno da intelecção humana. Então a convicção da unidade indissociável entre o sentir e o inteligir iluminou, a nosso ver, a maior crise do pensamento atual, quando, desde os gregos foi-se consolidando a separação e até oposição que chamamos de "esquizofrenia" intelectual.

${ }^{13}$ ZUBIRI, X., El hombre y Dios.

${ }^{14}$ Traduzida em português e publicado por É Realizações: ZUBIRI. X., Inteligência e realidade; ZUBIRI, X., Inteligência e logos; ZUBIRI, X., Inteligência e razão, em 2011, no formato de três livros.

${ }^{15}$ ZUBIRI. X., Inteligência e realidade, prólogo, III. 
E como Zubiri chegou à inteligência senciente? O filósofo, como Platão, até ficar exausto, ${ }^{16}$ passou a vida esquadrinhando a realidade, a fim de encontrar uma via libertadora da inteligência concipiente, que marcou, desde os gregos, a cultura e a teoria do conhecimento. O conhecimento a partir da "teoria" antecede a realidade, a qual tem de encaixar-se na teoria de qualquer forma. Ou seja, a realidade é obrigada a enquadrar-se no conceito. É um caminho às avessas, porque o primário não é o conceito, mas a realidade. E quando Zubiri conseguiu formular que estruturalmente tanto o sentir é intelectivo quanto o inteligir é senciente, pois são momentos de um único ato de apreensão senciente, cunhou a expressão "inteligência senciente", para garantir a realidade como experiência daquilo que fica em nossa apreensão do real. Para a dimensão missionária da pastoral o conhecimento caracterizado como transmissão de conceitos e não de experiência é um desastre, na medida em que o testemunho é o argumento mais forte na missão. E testemunho é fundamentalmente experiência compartilhada. Então experiência é uma determinação imperiosa para o conhecimento; experiência, para Zubiri é provação física da realidade em seus diversos modos. ${ }^{17}$

\section{O que é realidade?}

Zubiri dedicou-se a compreender o real, como ponto de partida da intelecção senciente. Até então a Filosofia, partindo do ser, entificou a realidade. Para o nosso filósofo, o real é aquilo que tem substantividade. Por isso é físico. Zubiri usou o exemplo da luminária e da luz para mostrar que o primário é sempre o real (a luminária), com sua substantividade, e que a luz que vem da luminária e sobre ela se reverte, fazendo-a visível, é uma reversão que constitui o ser do substantivo. Então a luminária é a realidade, e a luz é o ser desta realidade. Se não houvesse a luminária, não haveria luz.

O brilho começa por ser algo em si mesmo e derrama sua luz ao redor. E unicamente na medida em que essa luz que se derrama em redor reflui sobre a própria luminária brilhante, que como brilho tem uma propriedade física e não meramente lumínica, nesta medida unicamente pode-se falar do ser do substantivo. Pode-se dizer que o brilho visto em sua própria luz, a luz

\footnotetext{
${ }^{16}$ Zubiri faz este testemunho no Posfácio da tradução brasileira do seu livro: Inteligência e realidade, p. 287.

${ }^{17}$ ZUBIRI, X., Inteligência e realidade, p. 197.
} 
que dele dimana de alguma forma, evidentemente, mas de uma maneira secundária. Quer dizer, temos primeiro a luminária, a realidade, temos depois a luz, o ser, e temos a luz revertendo da própria luminária da qual emerge, o ser revertendo sobre a realidade. Esta reversão é precisamente o que constitui o ser do substantivo ${ }^{18}$.

O real é tudo o que existe e que apreendemos como realidade. Zubiri descobriu que tudo parte do real. Algo é ser porque é real; existe porque é real, e não o contrário. $\mathrm{O}$ ser é somente substantivo quando se torna o reverso da realidade, ou seja, quando brota da realidade e reflui sobre a realidade, enquanto atualização.

O grande salto de Zubiri foi chegar à realidade como o que fica em nossa apreensão do real. Para tanto é preciso ter inteligência. Só o humano pode fazêlo. Por isso é considerado "animal de realidades": "vertido para a realidade, o homem é por isso animal de realidades: sua intelecção é senciente, seu sentimento é afetante, sua volição é tendente". ${ }^{19}$ Isto constitui a essência da realidade humana. ${ }^{20} \mathrm{E}$ por ser animal de realidades, o homem é um "animal pessoal", isto é, vertido à pessoa. ${ }^{21}$ Por isso, "o homem é a voz da realidade". ${ }^{22}$ E o que então é a realidade, enquanto aquilo que fica do real na apreensão humana? A realidade está no real, mas é maior do que o real. Neste sentido a realidade é transcendente na apreensão mesma. E juntando com a tese de que Deus é o fundamento da realidade, todas as realidades estão vertidas a Deus por meio da sua presença fundamentante: ${ }^{23}$ "Deus não é objeto; é fundamento". ${ }^{24}$

Façamos o caminho zubiriano partindo da realidade em direção a Deus. Para Zubiri, realidade, "não designa um objeto, senão a maneira como o objeto 'fica' no enfrentamento humano". ${ }^{25}$ Portanto realidade é uma maneira como a coisa apreendida primariamente fica "na minha apreensão". ${ }^{26}$ Neste sentido, "as coisas reais não são a realidade, mas

\footnotetext{
${ }^{18}$ ZUBIRI, X., Estrutura dinámica de la realidad, p. 26-27.

${ }^{19}$ ZUBIRI. X., Inteligência e realidade, p. 208.

${ }^{20}$ ZUBIRI, X., El hombre y Dios, p. 46.

${ }^{21}$ ZUBIRI, X., El hombre y Dios, p. 66.

${ }^{22}$ ZUBIRI, X., El hombre y Dios, p. 104.

${ }^{23}$ ZUBIRI, X., El hombre y Dios, p. 104.

${ }^{24}$ ZUBIRI, X., El hombre y Dios, p. 158.

${ }^{25}$ ZUBIRI, X., El hombre y Dios, p. 22.

${ }^{26}$ ZUBIRI, X., El hombre y Dios, p. 104.
} 
somente vetores desta". ${ }^{27} \mathrm{Ou}$ como diz ainda nosso filósofo, "todas as coisas são reais, mas nenhuma é 'a' realidade". ${ }^{28}$ Significa que, embora a realidade nunca esteja fora do real, ela é maior do que as coisas reais. E o que é essa realidade que está em toda coisa real e que é maior do que elas? "Esta realidade não é uma coisa concreta a mais, porque não é 'uma' simples realidade; é o fundamento "da' realidade". ${ }^{29}$ Assim conclui Zubiri: "logo existe outra realidade em que se funda 'a' realidade. É justamente a realidade de Deus". ${ }^{30}$ Portanto Deus existe e está constituindo formal e precisamente a realidade de cada coisa. Por isso Deus é o fundamento de cada coisa e do poder do real que se manifesta nela. ${ }^{31}$ Então pela via da realidade se chega à prova da existência de Deus. Zubiri parte da realidade criada até chegar à Suprema Realidade criadora. Então Deus não é uma simples realidade concreta a mais entre as outras realidades, mas é a Realidade que fundamenta a realidade de todas as coisas criadas. E ao fundamentar, faz com que toda realidade tenha "atualidade".

\section{A respectividade}

Outro grande salto do realismo zubiriano é o que ele chama de respectividade. Todas as realidades (coisas) dizem respeito umas às outras. Nada está solto ou isolado. E cada realidade diz respeito à outra num sentido muito preciso que Zubiri chama de "dar de si". Significa que cada realidade dá de si à outra. "O dar de si é um momento intrínseco e formal das coisas". ${ }^{32}$ Isto é funcionalidade, pois é assim que as coisas funcionam. ${ }^{33}$

Cada realidade é constituída pelas notas essenciais e as notas aderentes ou adventícias. As notas essenciais compõem uma estrutura sem a qual não há realidade, isto é, não há aquilo que é "de seu” ou próprio. As notas aderentes ou adventícias são aquelas notas que não pertencem à essência, mas se juntam a ela para enriquecer sua realidade. Conforme o caso, as notas aderentes, têm grande importância, como é o "lugar". As essências

\footnotetext{
${ }^{27}$ ZUBIRI, X., El hombre y Dios, p. 108.

${ }^{28}$ ZUBIRI, X., El hombre y Dios, p. 104.

${ }^{29}$ ZUBIRI, X., El hombre y Dios, p. 104.

${ }^{30}$ ZUBIRI, X., El hombre y Dios, p. 104.

${ }^{31}$ ZUBIRI, X., El hombre y Dios, p. 149.

${ }^{32}$ ZUBIRI, X., Estructura dinámica de la realidad, p. 61.

${ }^{33}$ ZUBIRI, X., Estructura dinámica de la realidad, p. 61.
} 
das realidades são substantividades, ou seja, sistemas de notas suficientes na ordem da constituição. ${ }^{34}$

Umas das notas aderentes mais importantes é o lugar, pois ele não participa da essência de cada coisa e, no entanto, não há nenhuma coisa que não ocupe um lugar. "Tudo o que é real está em alguma parte" ${ }^{35}$ Então o lugar que um corpo ocupa respectivamente aos demais é o espaço: ${ }^{36}$ "a respectividade que se funda justamente na ocupação do lugar é o que chamamos espaço". ${ }^{37}$ Se respectividade é "dar de si", o lugar que uma coisa ocupa é uma forma de dar de si. As coisas que compõem o espaço litúrgico são realidades-sentido, porque têm a finalidade de movimentar as realidades criadas, sobretudo a realidade pessoal humana, em direção à Suprema Realidade criadora. Então tais realidades participam das três estruturas fundamentais e essenciais do espaço: "Junto a, em direção para, e a distância de". ${ }^{38}$ O que no espaço litúrgico fica junto a que? O que está em direção para? Qual é a justa distância de cada coisa? Se estas estruturas fundamentais e essenciais não forem respeitadas, o espaço perde seu sentido. São os grandes desafios da arte e da arquitetura contemporânea, que, se não considerar as estruturas fundamentais e essenciais do espaço, pode deixar-se levar pelo consumo obsessivo da "modernidade líquida". ${ }^{39} \mathrm{Da}$ mesma forma o rito sagrado, enquanto locus do encontro com o amor do Pai por meio de Jesus na força do Espírito mantém a dinâmica espacial, que precisa ser respeitada. Hoje se discute se o ósculo da paz tem seu melhor lugar no final da liturgia da Palavra ou antes do rito da comunhão.

\section{A estrutura dinâmica da realidade}

Agora vamos falar do dinamismo da realidade em Zubiri para compreendermos a dinâmica da liturgia. Considerando que o "Universo inteiro está em

\footnotetext{
${ }^{34}$ ZUBIRI, X., Estructura dinámica de la realidad, p. 105.

${ }^{35}$ ZUBIRI, X., Estructura dinámica de la realidad, p. 112

${ }^{36}$ ZUBIRI, X., Estructura dinámica de la realidad, p. 113.

${ }^{37}$ ZUBIRI, X., Estructura dinámica de la realidad, p. 113.

${ }^{38}$ ZUBIRI, X., Estructura dinámica de la realidad, p. 115.

${ }^{39}$ A expressão Modernidade líquida foi criada e consagrada pelo filósofo Zygmunt Bauman para denotar o modus essendi da Modernidade atual, caraterizada pela dissolução sistemática dos valores, a fim de promover o consumo desenfreado e radical.
} 
movimento", ${ }^{40}$ e este movimento se dá em e por si mesmo, ${ }^{41}$ então é o Universo que movimenta as coisas, e não as coisas que movimentam o Universo. Zubiri afirma que toda realidade é dinâmica, e seu dinamismo é um dar de si. O espaço litúrgico é uma nota aderente de grande peso para a arquitetura do ambiente celebrativo. Vamos, com Zubiri, percorrer as formas do dinamismo da realidade para compreender o dinamismo do espaço litúrgico e da ação litúrgica. Tal dinamismo tem cinco modalidades: Variação, Alteração, Mesmidade, Suidade e Convivência. Em primeiro lugar, é preciso considerar que estas modalidades têm a ver com o "dar de si" em ordem crescente, isto é, cada uma supõe a outra numa espécie de substrato. Neste caso Zubiri não trabalha com a oposição, mas com a suposição de que o precedente está incluído no consequente em forma dinâmica de crescimento e maturidade. Talvez seja esta uma das virtudes mais salientes que dá ao nosso filósofo a possibilidade de criticar toda a Filosofia ao longo da história.

\subsection{Dinamismo da variação}

Todas as coisas estão em movimento, mas é preciso estar atento a essa mudança que Zubiri chama de variação, pois "mudar é justamente um dar de si, mas é o mínimo". ${ }^{42}$ Aliás, o movimento radical é a mudança de lugar. E essa mudança não é essencial, pois mudar de lugar é o que Zubiri chama de variação. Embora seja a base de todos os outros movimentos em que consiste o dinamismo da realidade, é uma mudança periférica, mas que pode confundir o eixo da celebração, se, por exemplo, a liturgia da Palavra fosse mudada para depois da comunhão. Tratar-se-ia, portanto, de uma mudança externa e não essencial e, por isso, representaria o mínimo do dar de si. O espaço litúrgico está vertido para a liturgia. Por isso quando se planeja um espaço dessa natureza, se está tratando de uma realidadesentido. Então é algo feito para durar, algo que represente a essência do tempo, a eternidade. É durar o máximo para que a variação seja mínima, possibilitando o dar de si em dinamismos mais profundos do que a variação. Se a dinâmica do espaço e das ações litúrgicas se ativessem à variação, a arte e o rito seriam banidos como acontece em forma de abuso. Tudo estaria a serviço do consumo. Um desafio da arquitetura sacra atual e de certas

\footnotetext{
${ }^{40}$ ZUBIRI, X., Estructura dinámica de la realidad, p. 118.

${ }^{41}$ ZUBIRI, X., Estructura dinámica de la realidad, p. 120.

42 ZUBIRI, X., Estructura dinámica de la realidad, p. 108.
} 
interpretações da reforma litúrgica desprovidas de arte e beleza ${ }^{43}$ criam obstáculos à realidade humano-pessoal, que é vertida à Suprema Realidade criadora. Se isso não for considerado e se continuar essa tensão insana de variar com adendos externos ao rito, corre-se um risco duplo: de um lado os templos que representam verdadeiros monumentos de arte e arquitetura sacra do passado podem se tornar museus, e de outro, quando se quer construir algo adequado para o culto cristão, se volta simplesmente para a arte do passado. São os famosos neos. A execução dos ritos também passa pela mesma dificuldade, e a inculturação se torna quase impossível, quando foi na liturgia romana das origens uma demonstração impressionante de fé e atualização. Cada tempo tem sua arte, mas é preciso que realmente seja arte. Para ser arte é necessário que tenha o poder do real. A arte que não atrai por si mesma é ideológica. Toda arte e toda liturgia a serviço de uma ideologia já nascem mortas. A variação necessária no rito, como as leituras, as preces, cores litúrgicas etc. já estão dadas como limites obrigatórios, mas não fogem do simbólico. Não inventar é um dever dos ministros litúrgicos. Isto prejudica o dinamismo da liturgia. E não é desse tipo de mudança que trata a Constituição Sacrosanctum Concilium (SC), ${ }^{44}$ primeiro fruto do Concílio Vaticano II. Atribuir ao Concílio Vaticano que a liturgia dever variar continuamente é uma hermenêutica extremamente pobre e equivocada, que, quiçá, seja o reflexo de uma "modernidade líquida" a serviço do consumo obsessivo ou de uma contundente falta de fé. Se o rito não tivesse o poder da realidade dado pelo seu divino Fundador, então seria necessário se apoiar em show mens para buscar a eficácia da liturgia. O que acabamos de afirmar sobre o dinamismo da variação, de certa forma Ratzinger fala da inculturação, quando reduzida a mudanças exteriores:

A inculturação que se reduz apenas a uma mudança de formas exteriores não é de fato inculturação, mas o seu mal-entendido. Geralmente acaba por ofender as comunidades culturais e religiosas, com modalidade muito superficial e exterior, tomando como empréstimo suas formas litúrgicas. ${ }^{45}$

\footnotetext{
${ }^{43}$ Sobre arte e beleza na liturgia, ler: ASSEMBLEIA PLENÁRIA DOS BISPOS, Via pulchritudinis; CASSIGENA-TRÉVEDY, F., La belezza de la liturgia; COSTA, V. S., Noções teológicas de liturgia; COSTA, V. S., O amor de Deus; NAVONE, J., Em busca de uma teologia da beleza; PASTRO, C., O Deus da beleza.

${ }^{44} \mathrm{SC} 1$.

${ }^{45}$ RATZINGER, J., Introdução ao Espírito da Liturgia, p. 166.
} 
Agora, seguindo pensamento zubiriano, vamos buscar os dinamismos mais profundos, os quais têm a variação como estrato radical, mas não se atêm a ela. $\mathrm{O}$ importante a frisar é que tais dinamismos exercem um maior dar de si.

\subsection{Dinamismo da alteração}

O dinamismo da alteração é mais profundo porque envolve o dar de si de essências e não de aderências. Zubiri fala de três formas de alteração: transformação, repetição e gênese. Pensemos que o espaço litúrgico e a celebração ritual da fé são realidades-sentido para ajudar-nos no acesso à Suprema Realidade criadora: Deus. Então a alteração tem o mínimo de variação e máximo de transformação. A essência humana e a essência divina encontram-se em um dar de si em que a essência humana se transforma e sofre (passio) a gênese da "nova criatura", segundo Paulo. Isso tem que estar alicerçado no patamar do símbolo, como pensa Jung. Toda liturgia que prima pelo dinamismo de variação é superficial e pode cair em pedagogias fúteis ou se tornar diversão. Liturgia assim é pobre e inadequada ao seu fim.

Nesse sentido, o espaço litúrgico e a própria celebração são locus de transformação da pessoa e recriação da esperança que pulsa em quem busca vida nova na liturgia. Espaço pobre de arte e liturgias desprovidas de formulários bem concatenados e enriquecidos de estilo e beleza, dando-se à insanas variações, são inadequados para a fé celebrada. Máximo de variação e mínimo de dar de si é o que essas experiências, produzem de fato.

Deixemos de lado o dinamismo da mesmidade, já que todos os seres vivos estão na luta da estabilidade para que o que eram antes continue sendo agora. Para isso paradoxalmente todos os seres vivos mudam para continuar sendo os mesmos. Mas não vamos nos deter nisso.

\subsection{Dinamismo da Suidade}

O humano, sendo um animal de realidades, por isso uma "essência aberta", ${ }^{46}$ é um animal que se enfrenta com as realidades como sendo suas. Isso é Suidade, "e o ser seu é justamente o que chamamos de pessoa". ${ }^{47}$ Quando o homem clama: Meu Deus, a divindade não é apenas uma realidade de seu,

\footnotetext{
${ }^{46}$ Para Zubiri, as essências não humanas são sistemas de notas fechadas em seu próprio construto. Já a essência humana é pessoal e aberta à realidade e a si mesma como realidade.

${ }^{47}$ ZUBIRI, X., Estructura dinámica de la realidad, p. 221.
} 
mas é uma realidade sua. A expressão de seu é a fina flor do pensamento zubiriano. "De seu" significa aquele conjunto de notas que faz com que cada coisa seja o que é. Mas a liturgia, além de ter as notas que a fazem ser o que é, também é o lugar onde a prece flui e alimenta a Suidade, fazendo que o homem seja seu próprio ser. Portanto, o espaço e a ação litúrgica alimentam o dinamismo da Suidade, tornando possível à pessoa rezar, porque oferece a possibilidade para isso. "Possiblidade é a estrutura primária e radical da qual pode haver finalidade e medição". ${ }^{48} \mathrm{E}$ qual a importância da liturgia como realidade possibilitante? É mover o homem na direção de Deus, a partir do poder do real. Esse poder tem a força de arrastar.

\begin{abstract}
Porque o que dá o sentido de todos os sentidos, o construto de todos os construtos e a condição de todas as condições, o poder de todos os poderes é justamente o poder do real enquanto real. O homem está movido, determinado, sempre pelo poder do real enquanto real. Este poder por ser isto, é um poder último. Ademais é um poder que constitui o recurso último de toda realidade possibilitante. ${ }^{49}$
\end{abstract}

Quando o poder possibilitante se apodera do homem, causa o que Zubiri chama de empoderamento. ${ }^{50}$ Aí a pessoa é realmente sua. É nesse sentido que a crítica a uma arte que não atrai por si mesma, seja ela antiga ou moderna, é radical no sentido da identidade da própria arte. O mesmo se diz de uma liturgia que não atraia por si mesma e que supostamente precise de interferências não rituais.

\title{
5.4. O dinamismo da convivência
}

Zubiri parte da convicção de que "a convivência pertence à estrutura de cada um dos homens" ${ }^{51} \mathrm{O}$ animal não convive com os outros membros da sua espécie, apenas exerce comunicações signitivas ao tom de resposta. Mas o ser humano é obrigado a conviver, porque "está afetado pelos outros enquanto que outros". ${ }^{52}$ Não basta dar respostas, mas é preciso que as respostas sejam

\footnotetext{
${ }^{48}$ ZUBIRI, X., Estructura dinámica de la realidad, p. 113.

${ }^{49}$ ZUBIRI, X., Estructura dinámica de la realidad, p. 235.

${ }^{50}$ ZUBIRI, X., Estructura dinámica de la realidad, p. 236.

${ }^{51}$ ZUBIRI, X., Estructura dinámica de la realidad, p. 252.

${ }^{52}$ ZUBIRI, X., Estructura dinámica de la realidad, p. 256.
} 
adequadas a seres de inteligência e de aparato psíquico-emocional. Então a convivência é um dado elementar da raça humana. É um dar de si em profundidade. Neste sentido, o espaço litúrgico e a celebração da fé são locus de convivência amorosa; jamais pensados como isolamento. Um dos grandes eixos da reforma litúrgica foi justamente a participação comunitária, lugar de encontro entre os que buscam relação com a transcendência. A separação ao modo de oposição entre presbitério e povo não faz parte da Tradição litúrgica. A recuperação da unidade da Assembleia litúrgica foi um ponto culminante na restauração litúrgica realizada pelo Concílio Vaticano II.

\subsection{O dinamismo como modo de estar no mundo}

O mundo aqui descrito não é o mundo pessoal nem a totalidade do universo (cosmo), mas é a respectividade de todas as realidades universais, conhecidas ou não. O estar no mundo envolve a descrição do tempo. Afora todas a teorias sobre o tempo, para Zubiri, "o tempo afeta constitutivamente o dar de si em seu momento de respectividade". ${ }^{53}$ Portanto o dar de si exige tempo. Pensemos no tempo litúrgico, um tempo que flui sem apressamentos nem delonga desnecessária. A execução dos ritos litúrgicos necessita de seu tempo justo. Nem a menos nem a mais. Tudo está previsto nos rituais. Então o tempo consiste em estar dando de si, realitas in essendo. Como consequência final, "cada uma das realidades substantivas é constitutivamente extática". ${ }^{54}$ Pois "o êxtase é pura e simplesmente a respectividade do dar de si". ${ }^{55}$ Nesta altura podemos dizer que o espaço litúrgico e a celebração da fé são extáticos. Por natureza são o lugar do êxtase. Esse é o movimento natural e suficientemente dinâmico da liturgia. Por falta de reconhecimento dessa dinâmica intrínseca e não externa da liturgia é que aconteceram tantos abusos, quiçá, promovidos com boa vontade. O grande erro foi julgar que o sujeito, entendido como o ministro litúrgico e a própria assembleia, é quem produz o dinamismo litúrgico. Temos que partir da tese zubiriana de que todo o Universo está em movimento. Esse movimento afeta a liturgia como obra de Deus na pessoa de seu Cristo. É o dinamismo que vem do próprio Espírito. Não é um pobre ministro que mexe "seus pauzinhos" para que a liturgia funcione.

\footnotetext{
${ }^{53}$ ZUBIRI, X., Estructura dinámica de la realidad, p. 294.

${ }^{54}$ ZUBIRI, X., Estructura dinámica de la realidad, p. 318.

${ }^{55}$ ZUBIRI, X., Estructura dinámica de la realidad, p. 318.
} 
Entrar no rito e no seu ritmo é uma obrigação de quem ajuda o povo de Deus a celebrar sua fé. O dinamismo da liturgia é dela mesma e a variação deve estar no seu limite saudável, sempre em função do símbolo. Variar sem critério é aprisionar a liturgia à vaidade humana e não permitir que ela dê o máximo de si que pode dar.

Se fora do Templo ou fora de uma ação ritual, poder-se viver a religação ${ }^{56}$ de Deus, quanto mais o será no espaço litúrgico e na celebração da fé! Como ilustração, apresentamos um poema de Adélia Prado, que expressa como um leão pode ser uma via de religação, em outras palavras, como um leão ligou a poetisa a Deus:

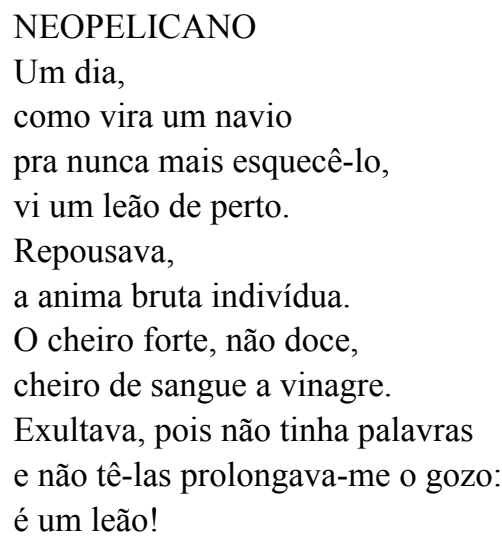

Só um deus é assim, pensei.

Sobrepunha-se a ele um outro e novo animal radiando na aura de sua cor maturada.

Tem piedade de mim, rezei-lhe premida de gratidão por ser de novo pequena.

Durou um minuto a sobre-humana fé.

Falo com tremor: eu não vi o leão, eu vi o Senhor!

("Neopelicano", Oráculos de Maio, 135) $)^{57}$

\footnotetext{
${ }^{56}$ A religação é um tema de grande importância em Zubiri e que não vamos desenvolver neste artigo. Esse tema pode ser estudado na obra: ZUBIRI, X., El hombre y Dios.

${ }^{57}$ HENRIQUES, J. A., A poesia de Adélia Prado.
} 
Então o "outro e novo animal radiando" na cor maturada do leão é a presença de Deus, que pela experiência de fé (sobre-humana fé) levou a poetiza a dizer: "falo com tremor, eu não vi o leão, eu vi o Senhor". Isto é religação.

Vejamos ainda a Missa que mudou os últimos dias de um dos maiores santos e doutores da Igreja: Tomás de Aquino. Ocorreu, na capela de São Nicolau, onde Tomás celebrava a missa matinal diária. ${ }^{58}$ Foi em 29 de setembro de 1273. Diz o relato:

Tomás ainda participa do capítulo de sua província, em Roma, na qualidade de definidor. Mas, algumas semanas depois - segundo Bartolomeu de Cápua, que recebeu esse relato de João del Giudice, que o soube por Reinaldo -, quando celebrava a missa na capela de São Nicolau, Tomás sofreu impressionante transformação (fuit mira mutatione commotus): “Após essa missa, nunca mais escreveu ou ditou qualquer coisa, e até mesmo se livrou de seu material de escrever (organa scriptionis); encontrava-se na terceira parte da Suma, no tratado da penitência". A um Reinaldo estupefato, que não compreende por que ele abandona sua obra, o Mestre responde simplesmente: "Não posso mais". Voltando a questioná-lo um pouco depois, Reinaldo recebe a mesma resposta: "Não posso mais. Tudo o que escrevi me parece palha perto do que vi". ${ }^{59}$

Tudo o que escrevi me parece palha perto do que vi. A obra do Doutor Angélico, permaneceu inacabada porque no final da sua vida terá tido uma experiência extática que ultrapassou de forma ingente tudo o que escrevera. Poder-se-ia dizer que aquela Missa foi como a última Ceia de Cristo, que revelou toda a poderosidade de um rito litúrgico, como experiência de Deus. Para nós, este fato é a maior crítica à teoria do conhecimento fundada na inteligência concipiente, que marcou a virada do primeiro milênio e, sem relativizar a obra de Tomás de Aquino, o fato nos mostra que a experiência de Deus, a qual só pode ser feita sencientemente, é maior e mais significativa que todos os conceitos sobre Deus. Nesse sentido, a mais humilde pessoa de fé pode fazer as mais altas escaladas da montanha a que a fé da Igreja nos leva todos os dias. Mas para isso é preciso contar com um espaço litúrgica que

${ }^{58}$ TORREL, J.-P., Iniciação a Santo Tomás de Aquino, p. 284.

${ }^{59}$ TORREL, J.-P., Iniciação a Santo Tomás de Aquino, p. 339. 
seja um recurso para tal experiência, e uma liturgia autêntica e de qualidade; espaço e liturgia extáticos.

\section{Conclusão}

Nesse estudo apoiamo-nos no realismo de Xavier Zubiri para argumentar nossa tese de que o dinamismo litúrgico, que se reflete também no espaço preparado para a liturgia, não provém dos ministros nem da assembleia, mas da ação divina infusa no próprio rito e na arte sacra impressa no espaço litúrgico. Interferir no dinamismo próprio da liturgia constitui em pecado, porque impede os fiéis de sentir o poder do rito e de ser apoderados por sua força. A liturgia como realidade traz consigo o poder do real que subjuga como um leão, que, enquanto via de religação, subjugou a poetisa. Imaginem a força da liturgia enquanto realidade!

Para nós, toda busca de dinamizar o espaço e a ação litúrgica que não leva em consideração o dinamismo próprio do rito e do espaço, ou que não respeita o tempo litúrgico enquanto um dar de si para que a ritualidade flua naturalmente, quebra o rito e cria mal-estar ou simplesmente transforma um momento delicado e simbólico em outra coisa, tipo diversão ou espetáculo.

Hoje estamos vivendo um momento difícil que parece não passar. Com razão está preocupando a todos, inclusive a autoridade da Igreja, mas curiosamente a coisa está acontecendo intermitentemente. São liturgias show, drones usados para transportar a Eucaristia em momento de adoração eucarística, padres montando "cavalinho" em plena homilia para mostrar como o demônio cavalga o humano e o subjuga pelo pecado, etc. Tudo isto pode ser comprovado em mensagens filmadas e enviadas por WhatsApp abundantemente. É uma espetacularização do rito sagrado e dos momentos devocionais, que cada vez mais entra no ritmo da variação, que segundo Zubiri é o dinamismo que menos dá de si na respectividade de todas as coisas, aqui do espaço e das ações rituais. Exatamente porque é um dinamismo de variação e não um dinamismo de transformação. O dinamismo de transformação implica a interação entre essências, ou seja, daquelas notas substantivas sem as quais a coisa não existiria. Por isso dizem respeito à essência e não à superfície. É o caso típico do simbólico. Neste sentido é que Jung fala de símbolo de transformação na missa. Descaracterizar o simbólico no mundo da liturgia é esvaziar o poder da realidade sagrada e ritual e abusar daquilo que pode salvar. 
A respectividade das coisas sagradas tratadas dessa forma é irrevogável falta de respeito. Seja ignorância ou falta de humildade e zelo pelo sagrado, isto faz um grande mal. Esperamos que venham dias em que não ocorra esse tipo de variação, e a liturgia flua em sua qualidade simbólica. Só assim poderemos encontrar a alegria cristã, que propõe Paulo $\mathrm{VI}^{60}$ ou a alegria do Evangelho que propõe Francisco. ${ }^{61}$

\section{Referências bibliográficas}

ASSEMBLEIA PLENÁRIA DOS BISPOS. Via pulchritudinis - o caminho da beleza: caminho privilegiado de evangelização e de diálogo. São Paulo: Loyola, 2006.

BERGER, R. Dicionário de liturgia pastoral: obra de consulta sobre todas as questões referentes à liturgia. São Paulo Loyola, 2010.

CAPONIGRI, A. R. A propósito de sobre a essência: o realismo de Xavier Zubiri. In: SECRETAN, P. (Org.). Introdução ao pensamento de Zubiri (1898-1983): Por uma filosofia da realidade. São Paulo: É realizações, 2014. p. 47-64.

CASSIGENA-TRÉVEDY, F. La belezza de la liturgia. Salamanca: Sigueme, 2008.

CONCÍLIO VATICAN0 II. Constituição Sacrosanctum Concilium sobre a Sagrada Liturgia. In: CONCÍLIO VATICANO II. Compêndio do Vaticano II: constituições, decretos, declarações. São Paulo: Vozes, 2015. p. 257-306.

COSTA, V. S. Direito litúrgico: um serviço à "lex amoris". Revista Pistis \& Práxis, v.7, n. 3, p. 729-747, set./dez. 2015.

COSTA, V. S. Noções teológicas de liturgia. São Paulo: Ave Maria, 2012.

COSTA, V. S. O amor de Deus: Teologia da redenção. São Paulo: Palavra e Prece, 2012.

COSTA, V. S. Viver a ritualidade litúrgica como momento histórico da salvação: participação litúrgica segundo a Sacrosanctum Concilium. 2.ed. São Paulo: Paulinas, 2010.

ELLACURIA, I. Uma abordagem da filosofia de Zubiri. In: SECRETAN, P.

\footnotetext{
${ }^{60}$ GD 94.
}

${ }^{61}$ EG 198. 
(Org.). Introdução ao pensamento de Zubiri (1898-1983): Por uma filosofia da realidade. São Paulo: É realizações, 2014. p. 33-45.

FERRAZ FAYOS, A. A trilogia sobre a inteligência. In: SECRETAN, P. (Org.). Introdução ao pensamento de Zubiri (1898-1983): Por uma filosofia da realidade. São Paulo: É realizações, 2014. p. 65-76.

FRANCISCO, PP. Exortação Apostólica Evangelii Gaudium - Alegria do Evangelho sobre o anúncio do Evangelho no mundo atual. 9.reimpr. São Paulo: Paulinas, 2015.

GRACIA, D. Zubiri (1898-1983). In: SECRETAN, P. (Org.). Introdução ao pensamento de Zubiri (1898-1983): Por uma filosofia da realidade. São Paulo: É realizações, 2014. p. 15-32.

HENRIQUES, J. A. A poesia de Adélia Prado. Disponível: <http://apoesiadeadeliaprado.blogspot.com/2014/06/o-tom-de-adelia-prado.html $>$. Acesso em: 17 jul. 2018.

JUNG, K. G. O símbolo da transformação da missa. 7.ed. São Paulo: Vozes, 2010.

LÓPEZ MARTÍN, J. La liturgia de la Iglesia: teología, hostoria, espiritualidade y pastoral. Madrid: BAC, 1996.

NAVONE, J. Em busca de uma teologia da beleza. São Paulo: Paulus. 1999.

PASTRO, C. O Deus da beleza: a educação por meio da beleza. São Paulo: Paulinas, 2008.

PAOLO VI, PP. Esortazione apostolica Gaudete in Domino. In: PAOLO VI, PP. Tutti i principali documenti (Latino-italiano). Vaticano: Libreria Editrice, 2002. p. 1585-1633.

PINTOR-RAMOS, A. Uma filosofia da religião cristã. In: SECRETAN, P. (Org.). Introdução ao pensamento de Zubiri (1898-1983): Por uma filosofia da realidade. São Paulo: É realizações. 2014. p. 77-108.

RATZINGER, J. Introdução ao Espírito da Liturgia. 4.ed. São Paulo: Loyola, 2015.

TEIXEIRA, J. A. P. A finitude do infinito: o itinerário teologal do homem em Xavier Zubiri. Lisboa: Universidade Católica, 2007.

TEJADA, J. F. Prefácio. In: ZUBIRI, X. Inteligência e logos. São Paulo: É Realizações, 2011. p. IX-XIX. 
TORREL, J.-P. Iniciação a Santo Tomás de Aquino: sua pessoa e sua obra. 4.ed. Petrópolis: Vozes, 2015.

ZUBIRI, X. EI hombre y Dios. 4.ed. Madrid: Alianza Editorial, 1998.

ZUBIRI, X. Estructura dinámica de la realidad. Madrid: Alianza Editorial, 1989.

ZUBIRI, X. Inteligência e logos. São Paulo: É Realizações, 2011.

ZUBIRI, X. Inteligência e razão. São Paulo: É realizações, 2011.

ZUBIRI. X. Inteligência e realidade. São Paulo: É Realizações, 2011.

Valeriano dos Santos Costa

Doutor em Sagrada Liturgia pelo Pontifício Instituto San'Anselmo Docente do Programa de Pós-graduação em Teologia da Pontifícia Universidade Católica de São Paulo São Paulo / SP - Brasil E-mail:pvalriano@uol.com.br

Recebido em: 04/09/18 Aprovado em: 28/04/19 